AESTHETIC MATERIALISM 



\section{Aesthetic Materialism}

ELECTRICITY AND

AMERICAN ROMANTICISM

Paul Gilmore

STANFORD UNIVERSITY PRESS

Stanford, California 2009 
Stanford University Press

Stanford, California

(C) 2009 by the Board of Trustees of the

Leland Stanford Junior University

All rights reserved

Parts of Chapter 3 were originally published in $A T Q$, Volume I6, No. 4, December 2002. Reprinted by permission of The University of Rhode Island.

No part of this book may be reproduced or transmitted in any form or by any means, electronic or mechanical, including photocopying and recording, or in any information storage or retrieval system without the prior written permission of Stanford University Press.

Library of Congress Cataloging-in-Publication Data

Gilmore, Paul.

Aesthetic materialism : electricity and American romanticism / Paul Gilmore.

p. $\mathrm{cm}$.

Includes bibliographical references and index.

ISBN 978-0-8047-6I23-9 (cloth : alk. paper)

I. American literature-I9th century-History and criticism.

2. Authors, American-Igth century-Aesthetics. 3. Electricity in literature. 4. Telegraph in literature. 5. Romanticism-United States. I. Title.

PS2I7.A35G55 2009

$8 \mathrm{IO} .9^{\mathrm{O}} \mathrm{OO} 3-\mathrm{dc} 22$

2008031223

Printed in the United States of America on acid-free, archival-quality paper

Typeset at Stanford University Press in Io/13 Galliard 
For Charlotte and Rowan

I have perceived that to be with those I like is enough, To stop in company with the rest at evening is enough, To be surrounded by beautiful curious breathing laughing flesh is enough.

To pass among them ... to touch any one ....

to rest my arm ever so lightly round his or her neck for a moment .... what is this then?

I do not ask any more delight . . . I swim in it as in a sea.

-Walt Whitman, "I Sing the Body Electric" 
